\title{
Laws to require purchase of locally grown food and constitutional limits on state and local government: Suggestions for policymakers and advocates
}

\author{
Brannon P. Denning ${ }^{2}$ \\ Samford University, Cumberland School of Law \\ Samantha Graff ${ }^{\text {b }}$ \\ Public Health Law \& Policy \\ Heather Wooten ${ }^{\mathrm{c}}$ \\ Public Health Law \& Policy \\ Submitted 30 April 2010 / Accepted 5 July 2010 / Published online August 2010 / Updated 20 October 2010 (see Erratum, p. 147) \\ Copyright (C) 2010 New Leaf Associates, Inc.
}

\begin{abstract}
Locally grown food laws that require, or provide incentives for, purchasing food grown within a defined geographic boundary are vulnerable to challenge under the U.S. Constitution's restrictions on local and state laws that discriminate against goods and commerce from other states, known as the dormant Commerce Clause doctrine (DCCD). Policymakers and advocates for local food should understand the impact of these restrictions and should take advantage of an important exception to these restrictions when drafting policies to encourage purchase of locally grown food. In
\end{abstract}

a 800 Lakeshore Dr., Birmingham, Alabama 35229 USA; bpdennin@samford.edu; +1 (205) 726-2413

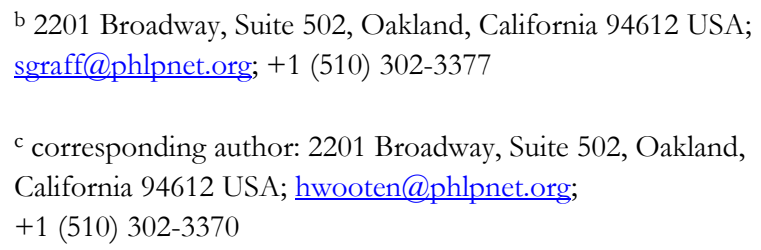

particular, they should (1) consider using the "market-participant exception" to the DCCD and tailor policies to apply to government's direct food purchasing or agreements with food service contractors; (2) avoid using tax credits and instead use direct cash subsidies when providing incentives for local food purchasing by private (nongovernmental) entities, and (3) make "locally grown" geographic definitions as broad as possible (especially to include out-of-state territory).

\section{Keywords}

Locally grown food, dormant Commerce Clause doctrine, economic development, public contracting

\section{Introduction}

A movement to eat locally is growing around the country, affecting food purchasing decisions of private and public consumers. Concerns about nutritional quality, food safety, environmental impact, and local economic loss associated with buying food from far-flung places have prompted 
the consideration of "locally grown food laws." Such policies encourage or require the purchase or use of locally grown food by private businesses and/or by governmental agencies.

Supporters argue that locally grown, minimally processed food not only is healthier, but it has a reduced carbon footprint because food need not be transported over great distances. Locally grown food also benefits local producers by keeping money circulating within local economy and providing jobs for community residents. And, locally grown food can minimize the risk of spreading food-borne illness by reducing the crosscontamination risks of aggregation (i.e., when a small amount of tainted food is mixed with a large amount of previously untainted food during processing or distribution), creating more transparency and accountability ("know your farmer, know your food"), and reducing the amount of time food spends in transit or storage. In short, local food is promoted to capture community values like health, fairness, environmental sustainability, and local economic development.

A small but growing number of communities have adopted or proposed policies on local food purchase, including Woodbury County, Iowa; Albany County, New York; Alexandria, Virginia; Cleveland, Ohio; and Iowa (Woodbury County, 2006; Albany County, 2009; Alexandria City Council, 2010; Cleveland City Council, 2010; Local Farmer and Food Security Act, 2010). For large cities especially, the amount of food affected by such a policy may be significant, covering such public facilities as hospitals, schools, children's and senior nutrition programs, recreation and community centers, and jails and juvenile facilities. However, even in communities where the amount of food purchased by a local government is not large, an important role of local purchase policies may be to serve as a "market primer." That is, the public sector provides a steady source of demand for local food that allows local producers to scale up and expand into other markets.

However, when drafting laws that promote locally grown food, policymakers and other advocates need to be aware of the U.S. Constitution's restraints on the ability of state and local governments to regulate interstate commerce, known as the "dormant Commerce Clause doctrine" (DCCD). For example, while it might be tempting to ban the sale of food grown outside a particular in-state geographic area in order to give an advantage to local producers, such laws would violate the DCCD's prohibition on discrimination against goods and commerce from other states. While we are not aware of any legal challenges to date on specific local food laws, we wish to raise awareness of potential legal roadblocks and how to avoid them. We have heard anecdotally that some cities or counties have expressed concerns about considering any local purchase policies due to legal questions about the DCCD and a lack of clarity on how avoid challenges.

Our approach in this paper is threefold. First we will provide a brief explanation of the DCCD. Then we will describe the impact of DCCD restrictions, and exceptions to these restrictions, on efforts to purchase local foods by governments, using several adopted and proposed local-purchase policies as case studies. Finally, we will provide a set of practical recommendations for drafting future policies that conform to DCCD restrictions and make use of its exceptions. Given the strained economic circumstances in which many state and local governments find themselves, communities want to make sure in particular that they are not buying a lawsuit when enacting laws on locally grown food.

\section{The Dormant Commerce Clause Doctrine in a Nutshell}

The U.S. Constitution grants Congress the power to regulate interstate commerce (U.S. Constitution art. I, \ 8, cl. 3). In addition, for over 150 years the U.S. Supreme Court has held that there are implied limits on state or local governmental power to regulate interstate commerce (Chemerinsky, 2006, p. 424). These limits are known as the "dormant Commerce Clause doctrine" ("DCCD”). ${ }^{1}$

\footnotetext{
1 The reason for the DCCD is largely historic. Power was
} 
The DCCD looks unkindly on state and local laws that discriminate against out-of-state goods or services - that is, treat out-of-state goods or services unfavorably compared to in-state goods or services-when federal law has not granted permission for such discrimination (Chemerinsky, 2006, p. 419). Were Congress to pass a law that, for example, expressly permitted states to require restaurants to serve a certain percentage of locally grown food, a state law doing precisely that would raise no DCCD concerns because it had been sanctioned by Congress.

\section{Strict Scrutiny for Discriminatory Laws}

If a law on discriminatory trade is challenged in court, the court will assess the validity of the law using a test known as "strict scrutiny." In theory, this means that in cases involving discriminatory laws, the government bears the burden of proving (1) a legitimate (i.e., nondiscriminatory or nonprotectionist) goal, and (2) that there are no lessdiscriminatory alternatives that would achieve that goal (Granbolm v. Heald, 2005). In reality, the application of strict scrutiny means that discriminatory legislation is presumed unconstitutional and nearly always invalidated (Chemerinsky, 2006, p. 431). For example, under the DCCD, Iowa could not pass a hypothetical law barring the import and sale of corn grown elsewhere, nor could it bar the export of Iowa corn to other states without an exceptionally good reason. Courts do not view the desires to improve the lot of Iowa farmers or keep all the corn grown in Iowa for Iowans as good reasons. Iowa would have to prove, for example, that non-Iowa corn was subject to a fungus that, if imported, could infect its corn (a nonprotectionist goal); and that no means for testing the imported corn for the fungus existed so it had no choice other than to exclude non-Iowa corn altogether (Maine v. Taylor, 1986).

centralized over interstate commerce in order to prevent interstate trade wars that plagued the new nation prior to the drafting and ratification of the Constitution in 1787. The Supreme Court has since presumed that the Constitution's framers did not intend for states to be able to disrupt what many refer to as our "national common market."
Even if a law does not explicitly refer to the geographical origin of goods or actors - that is, if the law is neutral on its face ("facially neutral") - it will be subject to strict scrutiny if a court finds that the law was passed with a discriminatory purpose or that in actual operation it has discriminatory effects (Bacchus Imports, Ltd. v. Dias, 1984; Hunt v. Washington State Apple Advertising Commission, 1977). For example, if Iowa banned the sale of some product that competes locally with corn (assume potatoes) but without specifying where the potatoes came from, and it could be established that the legislature's purpose in doing so was to help Iowa farmers compete against out-of-state competitors, then a court could apply strict scrutiny. Similarly, strict scrutiny would likely be applied to a facially neutral law banning certain kinds of corn hybrids not used in Iowa but grown elsewhere, assuming such hybrids exist. Because the ban would have the nearly identical effect as an explicit ban on the sale of out-of-state corn, courts would employ the strict scrutiny standard. Courts are not always clear, however, on how one proves discriminatory purpose or which effects will count as discriminatory (Denning, 2009).

\section{Balancing Test for Nondiscriminatory Laws}

Courts employ a "balancing test" when a law that affects interstate commerce is facially neutral and its purpose and effects are untainted by protectionism or discrimination (Pike v. Bruce Church, Inc., 1970). In contrast to strict scrutiny (which is likely to result in the invalidation of a challenged law), the balancing test is deferential to the government and often results in a court upholding the challenged law (Chemerinsky, 2006, p. 429).

The balancing test involves weighing burdens against benefits, asking whether the burden on interstate commerce "clearly exceeds" the local benefits claimed for the law. It is important to note that courts are not typically inclined to invalidate state and local laws under the DCCD's balancing test unless challengers demonstrate both (1) massive costs to interstate commerce and (2) benefits that are zero or nearly so (Bittker \& Denning, 2010, pp. 162-64). 
For example, instead of banning imports of out-ofstate corn, assume that Iowa passed a law requiring that corn storage facilities submit to inspection by Iowa officials to ensure safety and quality. Facilities owned by out-of-state business interests sue, claiming that compliance with the Iowa law imposes an undue burden on interstate commerce because it is very costly. Note that the law applies to all corn storage facilities, not just those owned by out-of-state firms; it is, therefore, truly evenhanded. Under the balancing test, the out-of-state owners would have to prove that the costs to interstate commerce clearly exceeded the local benefits-presumably, the benefits of ensuring that the facilities were safe for the storage of corn that humans and animals would consume. Given the importance of the latter goal, it is unlikely that a court would find the costs of compliance to be so great that it invalidated the nondiscriminatory inspection law.

\section{Avoiding Strict Scrutiny}

Because the test used (strict scrutiny or balancing) very nearly determines the outcome of DCCD cases, drafters of state and local "locally grown" laws that do not fit within an exception to the DCCD should ensure that such laws are written without reference to the state where goods or services originated. That is, they should strive for facial neutrality. But drafters should also remember that simple facial neutrality is a necessary but not sufficient condition for qualifying under the more lenient balancing test. Care should be taken that the law is not only facially neutral, but is also neutral in its purposes (i.e., its supporters are not suggesting that its real purpose is to favor in-state goods) and in its effects (that in actual operation it won't discriminate against out-of-state goods).

But what if a state or local government wants to impose an explicit preference for food grown within an in-state geographic area? All is not lost for advocates of locally grown food who want public leadership in this arena, because the DCCD has an important exception. If a law falls under this exception, it may survive a court challenge even if it is facially discriminatory.

\section{The Market-Participant Exception to the DCCD: An Opportunity for Laws on Locally Grown Food}

For advocates of locally grown food, the marketparticipant exception to the DCCD is an essential tool. This exception draws an important distinction between state or local governments acting as market regulators (such as when they impose a soda $\operatorname{tax}^{2}$ or ban the use of trans fats in restaurant food $^{3}$ ) and acting as market participants (by directly buying or selling goods) (Hughes v. Alexandria Scrap Co., 1976; Chemerinsky, 2006, pp. 451-52; Coenen, 1989; Williams, 2008). When state or local governments act as market participants, they are exempt from the DCCD. In other words, state and local governments can act as any private buyer or seller would in deciding with whom and on what terms they will deal. For example, imagine that the state of Florida passes a law prohibiting out-ofstate printing companies from bidding on state printing contracts. Under the DCCD, the law is facially discriminatory and one might expect a court to invalidate it. However, under the marketparticipant doctrine, the Florida law would stand, because Florida is "participating" in the printing services "market." Just as an individual or private business could make the decision to patronize only local businesses, state and local governments may do the same.

In order to ensure that the market-participant exception does not completely undermine the DCCD's antidiscrimination principle, this exception is limited in two significant ways. First, a state is not a market participant when it employs its authority to tax or exempt entities or transactions from taxation, because taxation is considered to be “a primeval governmental activity" (New Energy Co. v. Limbach, 1988). (Note that, somewhat illogically, the same rationale does not apply to cash subsidies. The government can be a market participant while

\footnotetext{
${ }^{2}$ A majority of states impose sales taxes on certain junk food and soda products. See www.impacteen.org/obesitystatedata. htm.

${ }^{3}$ A number of jurisdictions have banned the use of artificial trans fats in restaurant food. See www.bantransfats.com.
} 
providing cash subsidies, say, to grocers for their purchase of locally grown foods (Coenen, 1998).)

Second, states may not use their market power in one market to regulate the behavior of private individuals outside that market (South-Central Timber Development, Inc. v. Wunnicke, 1984). For example, assume Oklahoma owned some grain it wished to sell. Under the market-participant doctrine, the state would be within its rights to require that the purchasers of state-owned grain be state residents. But Oklahoma could not require that any purchaser of the grain have that grain milled in the state before the grain was exported. In placing this requirement, the state would be leveraging its entry into the grain market to regulate (not participate in) another market: the grain milling market.

Both limitations on the market-participant exception are understandable if one keeps in mind the basis for the exception: permitting governments to emulate private actors when choosing whether and on what terms to spend money or sell goods they have produced. Private parties lack the power to tax, and thus can not "participate" in a market by offering favorable tax terms to induce buying or selling. Similarly, private individuals ordinarily lack the power to control what happens to goods after they have been sold. A private grain seller, for example, could not force a buyer to use his brother-in-law's mill before the buyer can take away the grain.

\section{An Analysis of Laws on Locally Grown Food: Examples from the Field}

A law on locally grown food should be drafted with the market-participant exception to the DCCD firmly in mind so that if the law were found to be discriminatory, then the enacting jurisdiction would have a defense. Moreover, if drafting is done with an eye to falling within the exception, then those laws could, if desired, be designed specifically to benefit the locally grown food of a particular state.

In this section, we illustrate these points by referencing three concrete proposals:
1. Woodbury County, Iowa, "Local Food
Purchase Policy" (the "Woodbury Cou Policy"): This policy mandates that the county "shall purchase, by or through its food service contractor, locally produced organic food" for service in the Woodbury County jail, work release center, and juvenile detention facilities (Woodbury County, 2006).

\section{City of Cleveland, Ohio (the "Cleveland} Ordinance"): This proposed policy grants "Local Food," defined as food grown within a defined "Local Contracting Market," a two percent bid preference when contracting with the city (Cleveland City Council, 2010).

3. Iowa Local Farmer and Food Security Act (the "LFFSA"): This proposed law offers a 20 percent tax credit to grocers against the cost of purchasing "Local Farm Products," defined as "raw fruits, vegetables, grain, and meats that may be minimally processed for sale within the Local Territory" (Local Farmer and Food Security Act, 2010). "Local Territory," in turn, is defined as "the area within 150 miles of the reselling grocer that may include areas outside the State of Iowa" (Local Farmer and Food Security Act, 2010).

\section{Is the policy discriminatory?}

The first question to ask when assessing how these policies would fare under the DCCD is whether they are discriminatory. If a court found a policy to be discriminatory, the court would very likely invalidate the policy unless the market-participant exception to the DCCD applies.

The Cleveland Ordinance undoubtedly is discriminatory: not only does it define the "Local Food" subject to the bid preference as that produced within a few enumerated Ohio counties, but it also is explicit in its findings about its intent to benefit the local community. Note that the fact that some food grown in Ohio is excluded along with all food grown out-of-state does not save the ordinance from being discriminatory against outof-state growers (Dean Milk Co. v. Madison, 1951). 
The analysis is a bit more complex with regard to the Woodbury County Policy and the LFFSA. Since neither explicitly bars out-of-state products from being considered "locally grown" or "locally produced," these policies are not discriminatory on their face. But a court could find them to be either discriminatory in purpose (if it turns out that the hidden intent of the policies is to benefit local interests) or discriminatory in effect (if the benefits conferred are enjoyed mainly by in-state producers).

The Woodbury County Policy, for example, defines locally grown food as that which is "grown and processed within a 100-mile radius of the Woodbury County courthouse" in Sioux City, Iowa. It is plausible that a court could find that the policy is discriminatory in its purpose or effect because it excludes most out-of-state food. ${ }^{4}$

LFFSA's definition of "Local Territory," which explicitly includes areas outside Iowa, has accompanying legislative history indicating that drafters considered and rejected making the law "Iowa Farms Only." This antiprotectionist history might aid in rebutting claims that the law is discriminatory in its purpose. But if it turns out that few or no out-of-state grocers could take advantage of the tax credit, the LFFSA could ultimately be discriminatory in its effects.

\section{If the policy is discriminatory, how would it fare under strict scrutiny?}

As we have described, if a court were to find one of the policies to be discriminatory-and if the policy were not subject to any DCCD exception - the policy would almost surely be invalidated. Applying strict scrutiny, a court would examine the goal of the law encouraging locally grown food and the means for achieving that goal. If, as with the Cleveland Ordinance, the goal is stated as supporting local agriculture, ensuring a market for locally grown food, or something similar, that goal will most

${ }^{4}$ The Woodbury County example is further complicated by the fact that Sioux City is located on the border. The 100-mile radius would likely extend into neighboring states such as South Dakota and Nebraska. surely be seen as protectionist, virtually ensuring invalidation (again, assuming that a DCCD exception does not apply). Even if a court finds a nonprotectionist goal—say, obesity prevention, or pursuing sustainability or environmentalism-the court is unlikely to be convinced that the exclusion of food grown outside $\mathrm{X}$ miles from a geographical reference point is the only means to achieve that goal. However sympathetic courts might be with the goal of the law, they might be skeptical about the means chosen. Because of the feedback loop between goal and means, the availability of less discriminatory means might in turn make courts suspicious about the true goal of the ordinance; that is, is it really about environmentalism, or is it about insulating local farmers from outside competition?

\section{If the policy is not discriminatory, how would the balancing test apply?}

It is possible that a court would determine that a policy like the Woodbury County Policy or the LFFSA is not discriminatory. In that case, unless the policy were subject to a DCCD exception, the government would have to build a factual record ${ }^{5}$ sufficient to satisfy a court under the balancing test's lenient standard, i.e., that the costs to interstate commerce (likely to be not insubstantial because they would potentially be borne by all food producers outside the "locally grown" area) do not clearly exceed whatever putative local benefits are claimed for the ordinance. If such a factual record is not compiled (which could be included in the law's findings or a memo attached to the passage of the law), then a court might question whether there are local benefits or whether the benefits are minimal to nonexistent. The more it appears that the benefits are nonexistent or, worse, are pretextual, the greater the chance a judge would invalidate the ordinance, even under the forgiving balancing test.

\footnotetext{
${ }^{5}$ Even though under balancing the burden is on the challenger to demonstrate that the burdens are clearly excessive in light of the local benefits, defendants would certainly want to be ready with evidence of such benefits, if only to rebut allegations by the challenger that no such benefits exist, or that the claimed benefits are a pretext for discrimination or protectionism.
} 


\section{Can these policies claim the market-participant exception?}

To avoid the uncertainty of how a DCCD analysis would play out, a government wishing to enact a locally grown food ordinance ought to craft policies that enable it to claim the marketparticipant exception to the DCCD.

Both the Cleveland Ordinance and the Woodbury County Policy present classic cases of the government acting as a market participant-and therefore falling outside the purview of the DCCD. Under both policies, the city is merely setting terms for how it will engage in the market for food and food-related services. Like any private market participant, it is entitled to spend its money buying local food. Such choices would be clearly open to private market participants - a restaurant, say, which decides to only serve locally grown, grassfed beef, or a consumer who decides to buy local.

In neither case does the government exercise power that is unavailable to a normal market participant. Neither jurisdiction is regulating the market by, say, requiring new restaurants to purchase locally grown food as a condition of an operating permit. Cleveland and Woodbury are not attempting to favor locally grown food through the tax code, so no "primeval governmental activity" is involved. Nor are these jurisdictions impermissibly reaching "downstream" by extending their influence past the market in which the government is participating. So Cleveland and Woodbury can rest assured that the DCCD is not a threat to their policies because they are protected by the marketparticipant exception.

In contrast, the LFFSA is unlikely to qualify for the market-participant exception. Instead of using its position as a market participant to bid up the market for locally grown food, Iowa employs a tax credit equal to 20 percent of the total amount paid for such food. If the LFFSA were deemed to be discriminatory, it would almost surely be struck down under strict scrutiny. (However, as discussed above, there is a decent chance that a court would consider such a law to be nondiscriminatory and would apply the much more lenient balancing test to uphold the law.) Since the use of tax credits to stimulate production is a "primeval governmental activity," the market-participant exception would not apply.

Note that Iowa could simply replace the tax credit with a direct subsidy to grocers for their purchase of locally produced goods. Since the case law establishes that subsidies may be offered on a discriminatory basis, the state could restrict the subsidy to goods purchased from Iowa farms only, as it originally contemplated doing with the LFFSA.

To insulate itself from a DCCD challenge, Iowa should either make the LFFSA truly evenhanded by removing the geographic reference (which likely would defeat the purpose of enacting such a law in the first place) or offer a subsidy instead of a tax credit. A switch to a subsidy could have an additional benefit: The overall costs of the program could be reduced by restricting the subsidy to locally produced food purchased from in-state (lowa) farms.

\section{Additional Legal Considerations}

In addition to the DCCD, policymakers should be aware of two legal frameworks that could, but are unlikely to, affect laws on locally grown food: The Privileges and Immunities Clause of the U.S. Constitution, and international trade law.

\section{The Privileges and Immunities Clause}

Article IV, section 2, of the Constitution, the socalled "Privileges and Immunities Clause" (PIC), requires each state to extend to citizens of other states all the "privileges and immunities" the state offers its own citizens (Chemerinsky, 2006, pp. 466-67; Denning, 2003). Article IV, section 2, is a constitutional mandate of equal treatment for outof-state citizens in matters such as the ability to ply a trade, to own property, and to pay taxes on the same terms as in-state citizens. If a state law discriminates against an out-of-state citizen, claims might be brought under both the DCCD and PIC.

There are at least three important differences between the DCCD and the PIC. First, the PIC 
lacks a market-participant exception. (United Building \& Construction Trades Council v. Camden, 1984). A locally grown food law that explicitly discriminates against out-of-state food, but which is insulated from a DCCD challenge by the marketparticipant exception, may still be challenged as discriminatory under the PIC. This makes the PIC sound of more concern than it is, for the second important difference between the DCCD and the PIC is that corporations may not invoke the PIC because the PIC does not treat them as citizens (Paul v. Virginia, 1869; Denning, 2003). This vastly reduces the incidence of PIC relative to DCCD challenges because a large percentage of DCCD cases are brought by corporations. Third, the PIC case law has evolved to focus mainly on the ability of an out-of-state citizen to come into a state and receive equal treatment with regard to applying for a job, buying property, and paying taxes - what the Court has characterized as "fundamental rights" (Baldwin v. Montana Fish \& Game Commission, 1978). So it is unclear whether the PIC would even apply to a locally grown food law because the right of an out-of-state grower to sell food to a government agency or instrumentality on equal terms with instate growers might not be regarded by courts as a "fundamental right."

The PIC looms far less large than the DCCD. Nonetheless, some jurisdictions might want to pursue the lowest-risk strategy when designing a locally grown food law to fall under the market participant exception to the DCCD. This strategy would head off a PIC challenge by including some food produced out of state in the definition of "locally grown."

\section{International Trade Law}

The United States is a signatory to the World Trade Organization's General Agreement on Tariffs and Trade (GATT). Article III, Section 4, of GATT prohibits favoring domestic over foreign goods in transactions that involve "like products." Conceivably a locally grown food law could be challenged under GATT for preferring domestic over foreign food. Such a challenge should have little chance of succeeding under the governing standards. Since a product is not considered "like" if a legitimate distinction can be made based on "consumer tastes and habits," there is a strong argument to be made that consumer preferences reveal that locally grown food is not "like" foreign grown food (World Trade Organization, 2001). Even if local and foreign food products were found to be "like" one another, a locally grown food law probably does not violate GAT'T because it is not favoring domestic over foreign products but instead is favoring local over all other products, domestic and foreign alike. Moreover, Article XX contains exceptions relating to health and environmental protection that could apply.

\section{Conclusion and Recommendations}

In sum, laws on locally grown food that require or provide incentives for purchasing food grown within a defined geographic boundary are vulnerable to challenge under the DCCD, especially if the geographic boundary excludes out-of-state food from qualifying as "locally grown," whether explicitly, in purpose, or in effect. However, under the market-participant exception, even a law defining locally grown foods to encompass only that food grown in the enacting state or a subarea of the state will be immune from DCCD scrutiny if the law applies to government purchasing.

Because the Court has held that the use of tax credits is a "primeval governmental activity," laws such as the LFFSA that rely on tax incentives rather than direct subsidies could not use the market-participant exception and would be vulnerable to invalidation under the DCCD. On the other hand, because the LFFSA includes outof-state produce in the definition of locally grown food, it might be found to be nondiscriminatory, leading a court to apply the more lenient balancing test.

To minimize the chances any law would be invalidated, drafters should 6 :

\footnotetext{
${ }^{6}$ These recommendations represent a general legal analysis of this issue. Advocates and policymakers should work closely with their local city attorney or county counsel when crafting new policies to ensure these policies are viable in the context of the given jurisdiction.
} 
- Decide whether to craft the law to fit under the market-participant exception to the DCCD.

- If the law is designed to fit under the marketparticipant exception:

o It should cover only food bought by the government itself or by firms that contract directly with the government to provide food to schools, jails, and the like.

o Subsidies to private entities to purchase locally grown foods should come in cash, not tax credits. Under the DCCD, cash subsidies can be restricted to the purchase of in-state food alone because of the DCCD's differential treatment of cash subsidies and tax credits. (Note that this approach has a small risk of triggering a PIC challenge.)

o It should apply only to food purchasing and should not attempt to favor other in-state industries by imposing "downstream" market requirements. For example, the law should not require that food be subject to some sort of in-state processing in order to be eligible for purchase.

- If the law does not fit under the marketparticipant exception (because, for instance, there is a good reason to regulate nongovernment-related purchasers or to offer tax credits):

o Define "locally grown" as broadly as possible, consistent with whatever demonstrable benefits flow from locally grown food. In other words, just how "local" does the food need to be in order to achieve the benefits intended by the law? Foodsheds are as much natural geographies made up of systems and ecosystems as they are political geographies of cities, counties, states and territories. Situating a local food purchase policy within a broad framework of healthy, sustainable purchasing may be helpful when defining a geography that best supports the policy goals. ${ }^{7}$

o At a minimum, such a law should copy the LFFSA's explicit inclusion of out-of-state food in its definition of locally grown.

\section{Erratum}

On 20 October 2010, the following correction was made to this article:

The second sentence on page 141 was updated from "So, for example, since the National School Lunch Act allows operators of all child nutrition programs to apply a geographic preference for locally grown food, a state law requiring school districts to favor locally grown food raises no DCCD concerns." to "Were Congress to pass a law that, for example, expressly permitted states to require restaurants to serve a certain percentage of locally grown food, a state law doing precisely that would raise no DCCD concerns because it had been sanctioned by Congress."

This correction was made at the authors' request because the initial hypothetical example could cause confusion in light of a USDA memo brought to their attention by a colleague.

\section{References}

Albany County. (2009). Establishing a local food purchasing policy for Albany County. Retrieved from http://eatbettermovemore.org/sa/policies/ pdftext/200903191727120.AlbanyLocalFood.pdf

Alexandria City Council. (2010). Alexandria green food resolution. Retrieved from http://eatbettermove more.org/sa/policies/pdftext/201004211410100. AlexandriaGreenFoodResolution.pdf

Bacchus Imports, Ltd. v. Dias, 468 U.S. 263 (1984).

Baldwin v. Montana Fish \& Game Commission, 436 U.S. 371 (1978).

Bittker, B. I. \& Denning, B. P. (2010). Bittker on the regulation of interstate and foreign commerce. (2010 Supp.) Frederick, MD: Aspen Law \& Business.

\footnotetext{
${ }^{7}$ See the Sustainable Food Policy Project for more information and ideas on developing sustainable food purchase policies for public and private entities: www.sustainablefoodpolicy.org.
} 
Chemerinsky, E. (2006). Constitutional law: principles and policies (3rd ed.) Waltham, MA: Wolters Kluwer Law $\&$ Business.

Cleveland City Council. (2010). Local producer, local food purchaser, and sustainable business preference code. Retrieved from http://www.gcbl.org/ system/files/cle localfood ord.pdf

Coenen, D. T. (1989). Untangling the market-participant exception to the dormant commerce clause. Michigan Law Review, 88, 395488.

Coenen, D. T. (1998). Business subsidies and the dormant commerce clause. Yale Law Journal, 107, 965-1053.

Dean Milk Co. v. Madison, 340 U.S. 349 (1951).

Denning, B. P. (2003). Why the privileges and immunities clause of article IV cannot replace the dormant commerce clause doctrine. Minnesota Law Review, 88, 384-415.

Denning, B. P. (2009). Reconstructing the dormant commerce clause doctrine. William \& Mary Law Review, 50, 417-516.

Granholm v. Heald, 544 U.S. 460 (2005).

Hughes v. Alexandria Scrap Co., 426 U.S. 794 (1976).

Hunt v. Washington State Apple Advertising Commission, 432 U.S. 333 (1977).
Local Farmer and Food Security Act, SSB. 3236, Iowa (2010).

Maine v. Taylor, 477 U.S. 131 (1986).

New Energy Co. v. Limbach, 486 U.S. 269 (1988).

Paul v. Virginia, 75 U.S. 168 (1869).

Pike v. Bruce Church, Inc., 397 U.S. 137 (1970).

South-Central Timber Development, Inc. v. Wunnicke, 467 U.S. 82 (1984).

United Building \& Construction Trades Council v. Camden, 465 U.S. 208 (1984).

U.S. Constitution, article I, $\int 8$, cl. 3.

Williams, N. R. (2008). Taking care of ourselves: state citizenship, the state, and the market. Obio State Law Journal, 69, 469-524.

Woodbury County. (2006). Policy for rural economic revitalization: Local food policy. Retrieved from http://www.agobservatory.com/library.cfm?refID $\equiv 96615$

World Trade Organization. (2001). Measures affecting asbestos and products containing asbestos dispute resolution. Retrieved from http://www.wto.org/ english/tratop e/dispu e/cases e/ds135 e.htm 